\title{
Altered drainage patterns in patients with melanoma and previous axillary dissection.
}

\author{
Caitlyn M. Johnson \\ Thomas Jefferson University \\ Charles Intenzo \\ Thomas Jefferson University \\ Michael Mastrangelo \\ Thomas Jefferson University \\ Kendra Feeney \\ Thomas Jefferson University \\ Adam C. Berger \\ Thomas Jefferson University \\ Follow this and additional works at: https://jdc.jefferson.edu/surgeryfp \\ Part of the Dermatology Commons, and the Oncology Commons \\ Let us know how access to this document benefits you
}

\section{Recommended Citation}

Johnson, Caitlyn M.; Intenzo, Charles; Mastrangelo, Michael; Feeney, Kendra; and Berger, Adam C., "Altered drainage patterns in patients with melanoma and previous axillary dissection." (2013). Department of Surgery Faculty Papers. Paper 124.

https://jdc.jefferson.edu/surgeryfp/124

This Article is brought to you for free and open access by the Jefferson Digital Commons. The Jefferson Digital Commons is a service of Thomas Jefferson University's Center for Teaching and Learning (CTL). The Commons is a showcase for Jefferson books and journals, peer-reviewed scholarly publications, unique historical collections from the University archives, and teaching tools. The Jefferson Digital Commons allows researchers and interested readers anywhere in the world to learn about and keep up to date with Jefferson scholarship. This article has been accepted for inclusion in Department of Surgery Faculty Papers by an authorized administrator of the Jefferson Digital Commons. For more information, please contact: JeffersonDigitalCommons@jefferson.edu. 
Altered Drainage Patterns in Patients with Melanoma and Previous Axillary Dissection

\author{
Caitlyn Johnson ${ }^{1}$, MD \\ Charles Intenzo $^{3}$, MD \\ Michael J. Mastrangelo², MD \\ Kendra Feeney ${ }^{2}$, MD \\ Adam C. Berger', MD
}

From The Departments of Surgery ${ }^{1}$, Medical Oncology ${ }^{2}$, and Radiology ${ }^{3}$; Thomas Jefferson University, Philadelphia, PA 19107.

Correspondence: Adam C. Berger, MD; 1100 Walnut Street, MOB, Suite 500;

Philadelphia, PA, 19107; phone-(215) 955-1622, fax-(215) 923-8222;

adam.berger@jefferson.edu 


\begin{abstract}
The incidence of melanoma is increasing rapidly in the United States. Sentinel lymph node biopsy is an important diagnostic tool in the treatment and staging of melanoma. However, many patients with melanoma will have had lymph node surgery for previous melanoma or breast cancer. We set out to examine alterations in drainage patterns in patients with previous axillary dissection for breast cancer. We reviewed four patients with truncal and/or extremity melanomas and examined their lymphoscintigraphy and drainage patterns. Three patients with truncal melanoma mapped to cervical lymph nodes and a fourth patient with an arm melanoma mapped to her previously dissected axilla. Sentinel lymph node mapping is still an important adjunct in patients with melanoma despite previous axillary dissection.
\end{abstract}

\title{
INTRODUCTION
}

Cutaneous melanoma, a malignancy of melanocytes, has been rapidly increasing in incidence over the past 30 years (1). In 2010, there was an estimated 68,000 new cases of melanoma and nearly 9000 melanoma-associated deaths (1). The staging, prognosis, and treatment algorithms of melanoma depend on the Breslow thickness, mitoses, and the presence or absence of regional and/or distant metastases (2). Melanoma preferentially spreads via the lymphatics, and metastases typically progress through afferent lymphatic channels to sentinel nodes before presenting in non-sentinel lymph node sites. The presence of malignancy in regional lymph nodes carries a high prognostic significance, lowering the 5-year survival rate to $50 \%$ (3). Therefore, SLNB is of paramount importance in the initial workup and subsequent management of cutaneous melanoma. 
We report 4 patients who presented with melanoma of either the upper limb or upper posterior trunk; each of the patients had a history of breast cancer treated via surgical resection, including axillary lymph node dissection. For melanomas of the upper limb and posterior trunk, the site of sentinel lymph nodes is the ipsilateral axilla $99 \%$ and $93 \%$ of the time, respectively (5). If the axillary nodal basin is surgically removed, as in the case of the 4 reported patients, the lymphatic drainage may follow an alternate pathway with the sentinel nodes located in different nodal basins. There is very little literature regarding sentinel lymph node localization in those patients whose lymphatic drainage is significantly altered. 


\section{METHODS}

This is a retrospective case review of an IRB-approved melanoma data base. Upon review, 4 patients were identified who had a history of a partial mastectomy with axillary node dissection for the treatment of breast carcinoma and later presented with a cutaneous melanoma in a location that classically drains to the axillary node basin. Each patient underwent preoperatively lymphoscintigraphy to identify sentinel lymph nodes.

\section{RESULTS}

Patient No. 1

A 36-year-old female underwent bilateral mastectomies, including right axillary node dissection in 1994 for right-sided breast carcinoma and. In April 2006, she presented with a 0.9 millimeter melanoma on her right forearm. After excision with $1 \mathrm{~cm}$ margins, SLNB was recommended; lymphoscintigraphy revealed a right axillary sentinel lymph node. Three sentinel lymph nodes were identified just posterior to the thoracodorsal nerve. The final routine and immunohistochemical stains of the lymph nodes were negative for melanoma.

\section{Patient No. 2}

A 38-year-old female underwent right modified radical mastectomy in 1981 for right-side breast cancer. In November 2006, she presented with a pigmented lesion on her right upper back. Biopsy was consistent with a malignant melanoma 0.5 millimeters in depth, Clark level IV. It was decided to proceed with a wide local excision and SLNB. Preoperative lymphoscintigraphy revealed a right supraclavicular lymph node. She underwent wide local excision of her melanoma and removal of 2 cervical lymph nodes which were negative for melanoma. Patient No. 3 
The third patient is a 79-year old female who previously underwent a left axillary dissection for a left back melanoma. She also underwent a right partial mastectomy and axillary lymph node dissection in 1999 for breast cancer. She presented in 2011 with a $3.7 \mathrm{~mm}$ thick, nodular melanoma with ulceration on her right upper back. The patient was advised to proceed with a wide local excision of the melanoma and SLNB. Preoperative lymphoscintigraphy revealed a right supraclavicular sentinel lymph node. The patient underwent wide excision and dissection of 2 cervical lymph nodes. The lymph nodes were negative for metastatic melanoma. Patient No. 4

A 73-year-old female treated in 1994 for right breast cancer with a partial mastectomy and axillary lymph node dissection. In November 2009, she presented with a lesion on her right posterior shoulder with biopsy consistent with a $0.7 \mathrm{~mm}$ melanoma. Re-excision of the lesion revealed an additional $4 \mathrm{~mm}$ of melanoma; SLNB was recommended. Lymphoscintigraphy revealed a supraclavicular sentinel lymph node. Subsequently, the patient underwent excision of two right-sided cervical lymph nodes which, on subsequent pathology were deemed to be free of melanoma. 


\section{DISCUSSION}

By definition, a sentinel lymph node is any lymph node that receives lymphatic drainage directly from the primary tumor. Within a particular nodal basin, a sentinel node is the first node to receive lymphatic drainage; therefore, the histology of the sentinel node if felt to be representative of all other nodes in the basin (6). Historically, the only way to successfully identify sentinel nodes was to perform a complete lymph node dissection and study the pathology of each individual node within that basin. With the advent of cutaneous lymphoscintigraphy in 1977, Fee and colleagues began to characterize lymphatic drainage patterns of melanoma (7). In 1993, Alex and Krag introduced the concept of performing lymphoscintigraphy with teachnetium-99m sulfur colloid followed by intraoperative use of a handheld gamma probe for a more precise localization of sentinel nodes (8). Currently, preoperative lymphoscintigraphy, intraoperative intradermal injection of blue-dye and use of the gamma probe are all used in conjunction to accurately identify sentinel nodes.

One of the most important prognostic factors for melanoma is the presence and/or absence of malignancy in the regional lymph nodes draining the primary tumor (4). For this reason, the use of lymphoscintigraphy and sentinel node biopsy (SNB) is routine practice in the workup of patients presenting with a primary cutaneous melanoma. SNB is recommended for all Stage Ia melanomas with adverse prognostic features (thickness $>0.75 \mathrm{~mm}$, lymphovascular invasion, positive deep margins, ulceration, and mitoses), Stage IB, Stage II, and in-transit melanomas.

However, there is no clear consensus on how to investigate lymphatic metastases in those patients with melanoma whose regional lymphatic basins have been surgically altered. There is no recommendation to proceed with SNB when the lymph node basin that classically contains 
the sentinel node has already been removed. In fact, some advocate that if lymphatic channels have been disrupted by previous surgery, lymphoscintigraphy is not indicated because nodes may be falsely identified as being sentinel (9). However, with the technological advancements in lymphatic mapping, it has become relatively common to detect sentinel nodes in nodal basins not previous thought to receive lymphatic drainage directly from the tumor. Studies report discordance between the drainage patterns identified via lymphoscintigraphy and the predicted pattern in $32 \%-62 \%$ of cases of truncal melanoma (2). Therefore, removing the lymphatic basin typically containing the sentinel node does not preclude the existence of sentinel nodes in other atypical nodal basins. Moreover, when entire lymph node basins have been removed, the lymphatic drainage patterns will alter their course to follow new and unexpected routes. In 2004, Sood et al reported four patients with a history of breast carcinoma who underwent lumpectomy and axillary lymph node dissection and subsequently developed recurrence in the same breast (6). Each of the patients underwent lymphoscintigraphy in the workup of their cancer recurrence. The results of lymphoscintigraphy showed altered lymphatic drainage patterns of the residual breast tissue and different sentinel node locations (6).

Our experience yielded similar results, suggesting that the removal of classically located sentinel lymph node basins does not preclude the existence of additional sentinel nodes. Results from three out of four patients demonstrate that although lymphatic drainage of the trunk is often to the axillary node basin, supraclavicular and cervical node basins may contain sentinel nodes which are potential sites of metastatic disease. The lymphoscintigraphy results of Patient 1 show that a sentinel node may even exist in what was previously felt to be completely dissected lymph node basin. Given that lymphoscintigraphy is minimally invasive and relatively inexpensive, it is a cost effective means to identify sentinel nodes and allow for an accurate biopsy. Based on our 
experience, lymphoscintigraphy and sentinel lymph node biopsy should be performed even if traditional sentinel nodal basins have been removed. 


\section{REFERENCES}

1. Jemal A, Siegel R, Xu J, Ward E Cancer Statistics 2010. A Cancer Journal for Clinicians 2010; 60: 277-300.

2. Yudd A, Kempf, Goydos J, et al. Use of Lymphoscintigraphy in Malignant Melanoma.

Radiographics 1999; 19: 343-353.

3. Urist MM. Surgical Management of Primary Cutaneous Melanoma. CA Cancer J Clin 1996; 46 (4): $217-224$

4. Mortan D, Chochran A, Thompson J, et al. Sentinel Node Biopsy for Early-Stage Melanoma: Accuracy and Morbidity in MSLT-1, an International Multicenter Trial. Annals of Surgery 2005; 242(3) 302-313.

5. Thompson JF, Uren RF, Shaw HM, et al. Location of Sentinel Lymph Nodes in Patients with Cutaneous Melanoma: New Insights into Lymphatic Anatomy. J Am Coll Surg 1999; 189:195206.

6. Sood A, Yousseff IM, Heiba SH, et al. Alernative Lymphatic Pathyway After Previous Axillary Node Dissection in Recurrent/Primary Breast Cancer. ClinNucl Med 2004; 29: 698702.

7. Fee HJ, Robinson DS, Sample WF, et al. The determination of lymph shed by colloidal gold scanning in patients with malignant melanoma: a preliminary study. Surgery 1978; 84: 626-632. 8. Alex JC, Krag DN. Gamma Probe Guided Localization of Lymph Nodes. Surgical Oncology $1993 ; 2: 137-143$.

9. Amersi F, Morton D. The Role of Sentinel Lymph Node Biopsy in the Management of Melanoma. Adv Surg 2007; 41: 241-256. 


\begin{tabular}{|c|c|c|c|c|c|c|c|c|}
\hline \multirow[t]{2}{*}{ Patient } & \multirow{2}{*}{$\begin{array}{c}\text { Breast } \\
\text { cancer } \\
\text { surgery }\end{array}$} & \multicolumn{4}{|c|}{ Melanoma } & \multirow{2}{*}{$\begin{array}{c}\text { Lymphoscintigraphy } \\
\text { Results }\end{array}$} & \multirow{2}{*}{$\begin{array}{l}\text { Operative } \\
\text { Findings }\end{array}$} & \multirow[t]{2}{*}{ Pathology } \\
\hline & & $\begin{array}{c}\text { Primary } \\
\text { Site }\end{array}$ & Thickness & Ulceration & $\begin{array}{c}\mathrm{T} \\
\text { Stage }\end{array}$ & & & \\
\hline 1 & $\begin{array}{l}\text { Bilateral } \\
\text { MRM }\end{array}$ & $\begin{array}{l}\text { Right } \\
\text { Forearm }\end{array}$ & $0.9 \mathrm{~mm}$ & $\mathrm{~N}$ & T1b & Right Axillary Node & $\begin{array}{l}\text { 3 lymph } \\
\text { nodes } \\
\text { identified } \\
\text { with Blue } \\
\text { Dye and } \\
\text { Neoprobe }\end{array}$ & $\begin{array}{l}\text { Negative } \\
\text { for } \\
\text { malignancy }\end{array}$ \\
\hline 2 & Right MRM & $\begin{array}{l}\text { Right } \\
\text { upper } \\
\text { back }\end{array}$ & $0.5 \mathrm{~mm}$ & $\mathrm{~N}$ & T1a & Right Cervical Node & $\begin{array}{c}2 \text { lymph } \\
\text { nodes } \\
\text { identified } \\
\text { with Blue } \\
\text { Dye and } \\
\text { Neoprobe } \\
\end{array}$ & $\begin{array}{l}\text { Negative } \\
\text { for } \\
\text { malignancy }\end{array}$ \\
\hline 3 & $\begin{array}{l}\text { Left partial } \\
\text { mastectomy } \\
\text { \& ALND }\end{array}$ & $\begin{array}{c}\text { Left } \\
\text { upper } \\
\text { posterior } \\
\text { trunk }\end{array}$ & $3.7 \mathrm{~mm}$ & $Y$ & T3b & $\begin{array}{l}\text { Right } \\
\text { Supraclavicular } \\
\text { Node }\end{array}$ & $\begin{array}{l}2 \text { lymph } \\
\text { nodes } \\
\text { identified } \\
\text { with Blue } \\
\text { Dye and } \\
\text { Neoprobe }\end{array}$ & $\begin{array}{l}\text { Negative } \\
\text { for } \\
\text { malignancy }\end{array}$ \\
\hline 4 & $\begin{array}{l}\text { Right partial } \\
\text { mastectomy } \\
\text { \& ALND }\end{array}$ & $\begin{array}{c}\text { Right } \\
\text { posterior } \\
\text { shoulder }\end{array}$ & $4 \mathrm{~mm}$ & $\mathrm{~N}$ & T4a & $\begin{array}{l}\text { Right } \\
\text { Supraclavicular } \\
\text { Node }\end{array}$ & $\begin{array}{c}2 \text { lymph } \\
\text { nodes } \\
\text { identified } \\
\text { with } \\
\text { Lymphazurin } \\
\text { Blue Dye } \\
\text { and } \\
\text { Neoprobe }\end{array}$ & $\begin{array}{l}\text { Negative } \\
\text { for } \\
\text { malignancy }\end{array}$ \\
\hline
\end{tabular}

MRM-modified radical mastectomy

ALND-axillary lymph node dissection

Figure Legends:

Figure 1- right upper back melanoma; anterior image obtained 15 minutes after radiotracer injection shows a right supraclavicular lymph node (arrow) superior to the injection site .

Figure 2-posterior shoulder melanoma; anterior image obtained 5 minutes subsequent to radiotracer injection demonstrates a right cervical sentinel lymph node (arrow) just lateral to the projection of the injection site. 
